\title{
Cobiax and post-tension slabs: A comparative study based on the construction duration time and cost
}

\author{
Haitham kannas $^{1^{*}, \text { Abdallah M. S. Wafi }}{ }^{1}$,Mahmoud AlHassan ${ }^{1}$ \\ ${ }^{1}$ Civil Engineering Department, Near East University, Nicosia, Via Mersin 10, Turkey
}

ARTICLE INFO

ARTICLE HISTORY:

Received: 19 January 2020

Revised: 21 August 2020

Accepted: 23 August 2020

Published: 23 August 2020

\section{KEYWORDS:}

Cobiax slab, post-tension slab, cost, execution duration

\begin{abstract}
A B S T R A C T
Slabs are one of the most basic components concerning the cost of the structure, because of the number of building materials utilized. It is of incentive to think about the current technologies available, meaning to make these slabs cost less or even improve its behaviour. Cobiax and posttension slabs systems show up as an appropriate alternative. In light of this reason, this paper focuses on demonstrating the advantages and disadvantages of both Cobiax and post-tension systems. Nowadays, these systems are very popular all around the world. It is very necessary to have a wide understanding of the differences in cost and the construction duration between these two systems and have good knowledge about the advantages and disadvantages of both types. Firstly, the properties of these types of slabs have been reported and the advantages and disadvantages for both systems and then the cost and time has been compared, which are the most important factors for the owners. Finally, it has been made a comparison between the reinforcement quantities, concrete quantities, final cost and duration to finalize the construction stage. As a result, it has been found that the post-tension system is more economical than the Cobiax system according to reinforcement quantities, on the other hand, Cobiax system is more economical in concrete quantities which leads to lighter buildings and fewer reinforcement quantities in foundations. When the construction duration has been considered, it has been found that the post-tension is the quickest system in the construction field because it is increasing the strength and durability of the structure which the Cobiax system cannot provide.
\end{abstract}

\section{INTRODUCTION}

The cost and the duration are both parameters that must be taken into consideration when choosing the slab type. Under those assumptions, this study compares both posttensioned with Cobiax slabs. The evaluation of the cost and time assessment will be carried out based on the study of the materials used for each type, the labour used and the transportation costs for each slab.

Cobiax slabs hollow biaxial section, biaxial voided slab, are fortified solid sections in which voids permit to decrease the amount of concrete used.

The principle impediment of solid developments, if there should be an occurrence of flat pieces, is the high weight which restrains the range. Therefore, a fundamental look into the field of the fortified solid structures have concentrated on upgrading the range, but before lessening the weight or beat common deficiencies in the concrete. The Pantheon in Rome, construct 125 advertisements, is one of the most conspicuous models in old history. Coffers, in spite of the fact that not fortified, were utilized to help the heaviness of the vault.

The development of the empty piece was in the 1950s. The empty pieces are pre-assembled, single direction spreading over, solid components with empty chambers. Because of the construction, these are modest, and decrease building time, yet can be utilized uniquely in a single direction traversing development, and should be upheld through shafts and additionally steady dividers. The piece has been particularly mainstream in nations where the accentuation of house development has been on ready-made concrete cement, including North European countries and communist nations of Eastern Europe. Precast solid prevalence is connected with low-seismic zones and progressively practical developments on account of the quick building get together, lower self-weight (less material), and so forth. In this essay, a few kinds of the new inventive innovation of a generation empty piece is presented (Viana, 2017). 
Post-tension is a newly released system, a new technology for reinforcing and strengthening concrete. It can be summarized that the post-tension system contains tendons which are steel bars with high yield strength approximately three times more than the normal reinforcement bars which took place inside metallic channels or ducts. The ducts are arranged in the slab with a specific profile at each point along the slab length before casting the slab. After concreting the slab with 24 hours the first stage of stress take place by applying a horizontal tensioning force by using a jacking machine for a certain limit, and after 72 hours the second stage of stressing take place. It is compulsory to check the tendons secured by using anchors against the slab edge to prevent tendons from slipping back inside the concrete. It is important to mention that the stressing should happen before allowing the slab to carry any kind of additional loading except its own weight. (Kang, 2011; Aalami \& Kelly, 2001).

\section{SLABS TECHNOLOGY OVERVIEW}

\subsection{Different examples of Cobiax slab}

\subsubsection{Airdeck}

It is licensed in 2003 and contains an upset plastic infusion shaped component that is a resonator in the low section during the generation procedure by an automated arm see Fig. 1. The benefit of this system reduces the time according to no required for holding lattice to hold down the voiding components during casting of the subsequent layer. As the containers can be settled, there are clear carriage points of interest versus other voiding frameworks. The fixed estimations are executed by standard Eurocode2 standards.

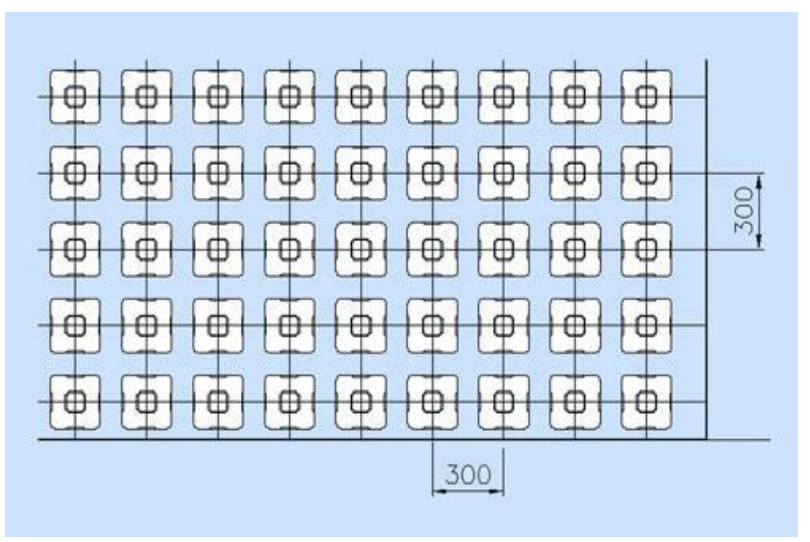

Fig. 1. The geometry of the airdeck slab (Churakov, 2014)

\subsubsection{Cobiax}

Cobiax system utilizes a hollow slab standard of making empty spaces inside the concrete to help the building structures Figs. 2 and 3. Circular and torus moulded hollow plastic individuals, named as hollow formers, are held set up by light metalwork for simple establishment between the upper and down support layers of a concrete slab (Albrecht, et al., 2012).

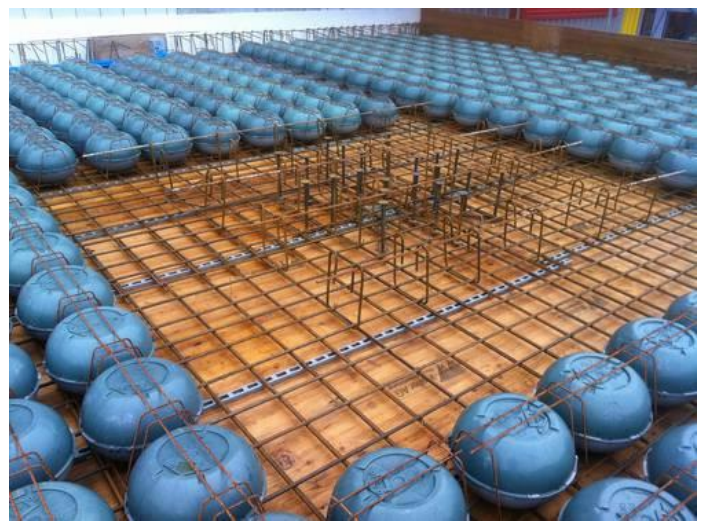

Fig. 2. Example of Installation of Cobiax Slab (Viana, 2017)

\subsection{3. $U$-boot}

The utilization of U-Boot Beton framework makes it conceivable to make mushroom columns, with the likelihood to have the mushroom in the thickness of the chunk.

Because of the conic lift foot, immerging the U-Boot Beton framework in the concrete flowing will make a gridwork of commonly opposite shafts shut from the base and the top by a level plate that is made with a solitary throwing; this outcome is a significant decrease in the utilization of cement and steel.

U-Boot Beton is utilized to make pieces with an enormous range, or that can bolster huge weights without bars.

Light and snappy and simple to position, because of their measured quality, the creator can change the geometric parameters varying to adjust to all circumstances with extraordinary engineering opportunity (Brandão, 2013).

\subsubsection{Polystyrene voiding locks}

The old way to reduce the weight of structural floors is to use polystyrene blocks to reduce the measurement of nearby concrete casting. This requires a massive consumption of human labour as demonstrated in Fig. 3. 


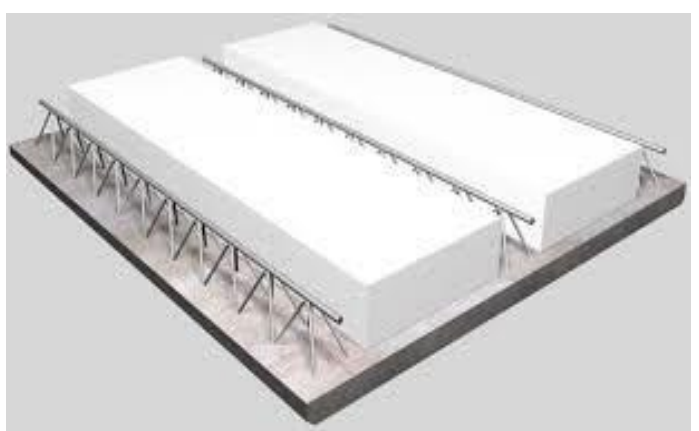

Fig. 3. Examples of voiding locks technology (Churakov, 2014)

\subsubsection{Bubble deck}

In the 1990s, another framework was developed, taking out the above issues Fig. 4. The purported bubble-deck innovation progressed by Jørgen Breuning, locks ellipsoids between the max and base support networks, along these lines making a characteristic cell structure, acting as a strong slab. Bubble deck slab is a strategy for taking out all concrete from the centre of a story piece, which is not playing out any basic capacity, in this way drastically lessening basic dead weight. High thickness polyethylene empty circles supplant the in-viable cement in the focal point of the section, along these lines diminishing the dead weight and expanding the proficiency of the floor. By acquainting the hole leads with a $30 \%$ to half lighter slab which diminishes the weights on the columns, shear walls and foundation, and obviously of the whole structure (Yadav et. al., 2018).

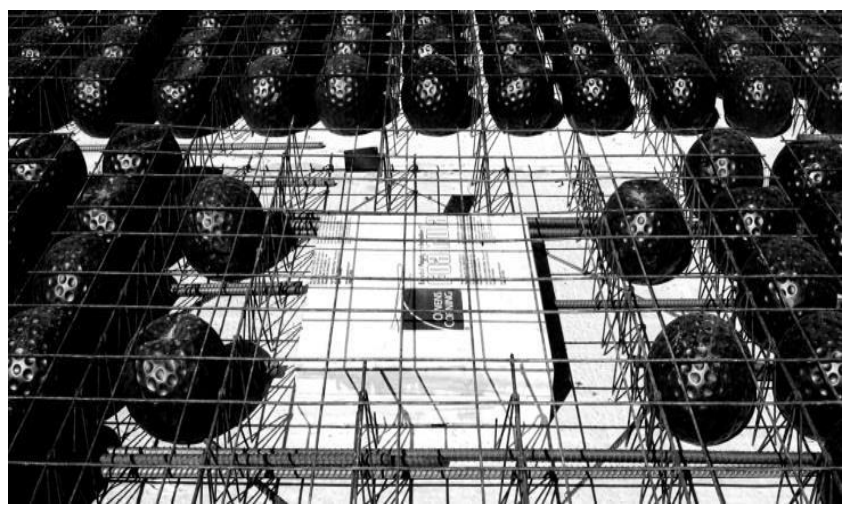

Fig. 4. Prefabrication of bubble deck slab

(Churakov, 2014)

\subsection{Post-tension slab}

It is imperative to know how and when it can be applied or think that the typical slab will be progressively efficient in the event that moving to the post-tension slab is required. In the PT design, it is desirable to draw moment diagrams to the pliable essence of the concrete section. The tensile face demonstrates what bit of the beam requires fortifying for strength. At the point when the moment is drawn on the tension side, the graph coordinates the general wrap of the tendons. The tendons change their vertical heights in the beam to follow the moment diagram. Strands are at the highest point of the beam over the support and approach the base at mid-range. Ordinarily, post-tension slabs begin to be increasingly practical with a range of more than 7 meters (Eurocode, 2004).

\subsubsection{Kinds of post-tension systems}

There are numerous kinds of post-tension systems dependent on the quantities of strands (mono and multi strands ), state of the duct (flat duct and round duct) and the size of the strand $12.7 \mathrm{~mm}$ and $15.2 \mathrm{~mm}$. The post-tension system itself A) Bonded system B) Unbonded system, which will be compared in Table 1. This table also shows the difference between bonded and unbonded systems (Hills, 2004).

Table 1. Difference between bonded and unbonded systems

\begin{tabular}{|l|l|l|}
\hline & Unbonded & Bonded \\
\hline $\begin{array}{l}\text { Expulsion and } \\
\text { slicing to } \\
\text { explicit length }\end{array}$ & Required & $\begin{array}{l}\text { Not necessary but } \\
\text { possible }\end{array}$ \\
\hline Placement & $\begin{array}{l}\text { Extremely } \\
\text { functional and } \\
\text { adaptable. Simple } \\
\text { to deal with and } \\
\text { does not require } \\
\text { heavy equipment }\end{array}$ & $\begin{array}{l}\text { Extremely functional } \\
\text { and adaptable. } \\
\text { Depending on the } \\
\text { system used, it may } \\
\text { require heavy } \\
\text { equipment }\end{array}$ \\
\hline Grouting & Cannot be applied & Required \\
\hline Stressing & $\begin{array}{l}\text { Stressing strand by } \\
\text { strand by using a } \\
\text { mono-strand } \\
\text { jacking machine }\end{array}$ & $\begin{array}{l}\text { Stressing by using } \\
\text { multi-strand jacking } \\
\text { machine }\end{array}$ \\
\hline Demolition & $\begin{array}{l}\text { Requires special } \\
\text { care }\end{array}$ & $\begin{array}{l}\text { Straight forward } \\
\text { (similar to regular } \\
\text { reinforcement }\end{array}$ \\
\hline
\end{tabular}

Applications of these two systems are used in construction (bridges, containment structures, etc.) as described by Freyermuth (1989):

- In the USA, the unbonded system is more famous in buildings construction,

- The bonded system is more known in civil structures,

- The two systems can be utilized as external posttensioning.

Selection of a system depends on:

- Availability,

- Cost,

- The special needs for the projects. 


\subsubsection{Materials used in post-tension}

The materials which are used in post-tension technology depends on the system types as what is has been mentioned above, but there is a common material with very small differences in the size and shape. The main material is strands which are made from a 7-wired high carbon steel wires with $12.7 \mathrm{~mm}$ or $15.2 \mathrm{~mm}$ diameter, Anchors made of heavy metallic material and it is used to combined the strands together to stress them easily at one time, Wedges are a metallic material. used to lock the strands from the stressing side to prevent it from slipping inside the concrete, the duct is the sheath for the post-tension strands, highdensity polyethene or galvanized steel pipes. All the above material combination results what called a post-tension tendon.

\section{ADVANTAGE AND DISADVANTAGES}

\subsection{Cobiax slab}

Advantages and disadvantages of Cobiax slab are given in Table 2.

Table 2. Advantages and disadvantages of Cobiax slab

\begin{tabular}{|l|l|}
\hline Advantages & Disadvantages \\
\hline $\begin{array}{l}\text { Saves 35\% of the weight of the } \\
\text { slab compared to a solid slab }\end{array}$ & Thicker slab sections \\
\hline Fewer materials required & Increase building height \\
\hline Reduced concrete usage & $\begin{array}{l}\text { Not widely available on the } \\
\text { market }\end{array}$ \\
\hline $\begin{array}{l}\text { Good resistance for fire and } \\
\text { good insulation }\end{array}$ & $\begin{array}{l}\text { Future modification for the } \\
\text { slab use is not } \\
\text { recommended }\end{array}$ \\
\hline $\begin{array}{l}\text { Reduction of about } 40 \% \text { of } \\
\text { column sizes }\end{array}$ & $\begin{array}{l}\text { Fast and cheap for making } \\
\text { walls and services }\end{array}$ \\
\hline $\begin{array}{l}\text { Fast and easy to design and } \\
\text { make any shape in the slab } \\
\text { edge }\end{array}$ & \\
\hline
\end{tabular}

\subsection{Post-tension slab}

Advantage and disadvantages of post-tension are given in Table 3.

Table 3. Advantage and disadvantages of post-tension

\begin{tabular}{|l|l|}
\hline Advantages & Disadvantages \\
\hline Efficient use of materials & Complexity of work \\
\hline Crack control & $\begin{array}{l}\text { Poor workmanship can lead } \\
\text { to accidents }\end{array}$ \\
\hline $\begin{array}{l}\text { Smaller deflections/thinner } \\
\text { members }\end{array}$ & $\begin{array}{l}\text { Future modification for the } \\
\text { slab use is not } \\
\text { recommended }\end{array}$ \\
\hline Corrosion resistance & $\begin{array}{l}\text { It requires good quality } \\
\text { control }\end{array}$ \\
\hline
\end{tabular}

\begin{tabular}{|l|l|}
\hline $\begin{array}{l}\text { Less material; reduced } \\
\text { environmental impact }\end{array}$ & $\begin{array}{l}\text { Complex stressing losses } \\
\text { are required }\end{array}$ \\
\hline $\begin{array}{l}\text { Less cost due to the less of } \\
\text { shuttering and plaster. Because } \\
\text { of flat soffit }\end{array}$ & $\begin{array}{l}\text { Pour strip is required in if } \\
\text { the slab length at any } \\
\text { direction is more than } 60 \\
\text { meters }\end{array}$ \\
\hline $\begin{array}{l}\text { Quick construction can } \\
\text { accomplish because the } \\
\text { framework can be removed } \\
\text { after stressing }\end{array}$ & \\
\hline Reduces building height & $\begin{array}{l}\text { Lower total cost of ownership } \\
\text { (maintenance) compared to RC } \\
\text { alternatives }\end{array}$ \\
\hline
\end{tabular}

\section{APPROXIMATE DURATION}

\subsection{Cobiax}

Cobiax sections are put on level chunk formwork with the extra time of putting the Cobiax modules set up. The fixing of the pens wherein the "balls" are situated to the base strengthening will contribute extra time to the erection procedure far beyond the insignificant position of the modules.

Cobiax slabs need a large number of labours. Steel reinforcement must be placed on the highest level of the formwork, the Cobiax modules must be placed and ordered in their right positions, the cages must then be fixed to the lowest reinforcement, and top reinforcement placed up after that. After this process, it requires a large number of workers so the concrete can be placed.

Also, it is important to mention that the removing of the formwork cannot be done less than 15 days, depends on span length (CobiaxUSA, 2020; Naik \& Joshi, 2017).

\subsection{Post-tension}

Post tension floors are much faster than any other system with the same surface area which is approximately the framework can be removed after 5 to 7 days for each slab (as soon as the stressing is done), time and money saved by achieving project target completion before the due date. The break-down structure for the duration can be as follows 1 day for slab formwork, 1 day for placing bottom mesh, 2 days for extra top reinforcement and punching shear reinforcement, 2 days for installation of the post-tension system.

\section{COMPARISON OF COST AND TIME FOR COBIAX AND POST-TENSION}

After having a good understanding about the two deferent systems a comparison has been made between the cost which contain the approximate material cost 
(reinforcement and concrete) quantities for the same structure with the same location and span lengths.

Fig. 5 shows the comparison between reinforcement quantity for post-tension system and Cobiax system. As per Fig. 5, it has been found that post-tension system reinforcement quantity is less than Cobiax which leads us to the fact that the cost of the post-tension slab is less than Cobiax slab when it has been studied based on the reinforcement quantity.

Fig. 6 shows the comparison between concrete quantity for post-tension system and Cobiax system.

As per Fig. 6, it has been found that post-tension system concrete quantity is more than Cobiax which leads us to the fact that the cost of post-tension slab more than Cobiax slab when it has been studied based on the concrete quantity.

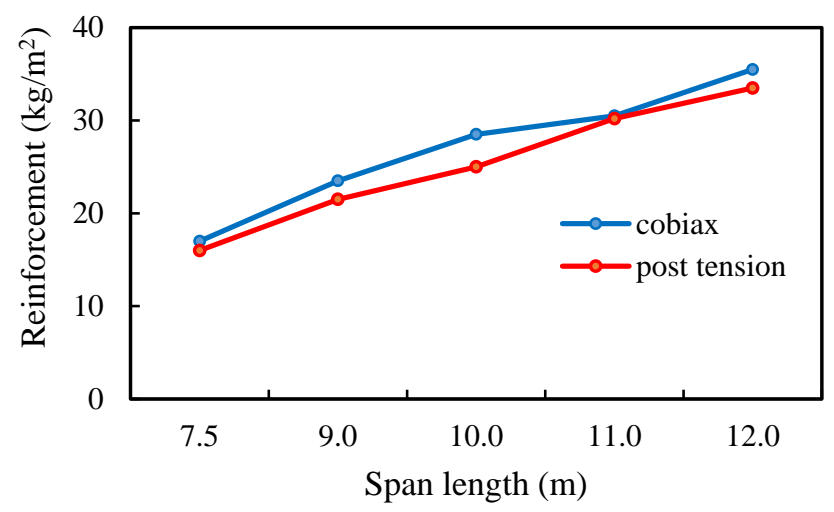

Fig. 5. Comparison based on reinforcement

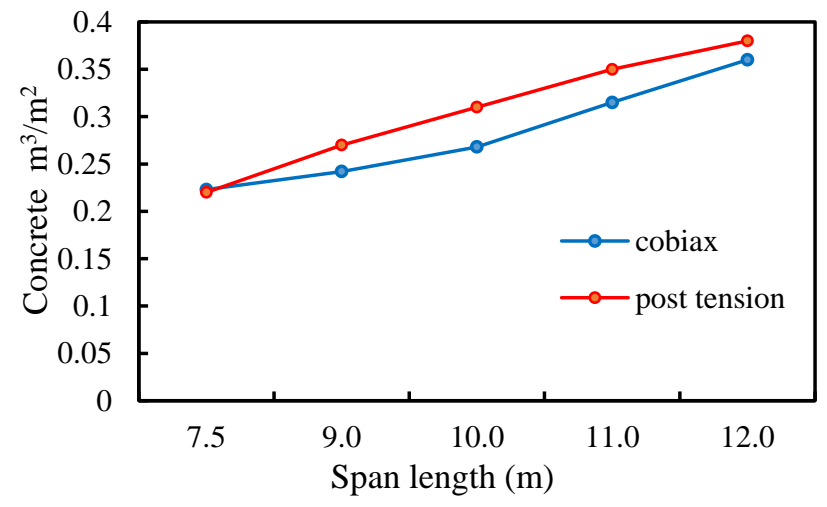

Fig. 6. Comparison based on concrete quantity

At $7.5 \mathrm{~m}$ span length concrete quantity is the same, but when the span length increased, the difference between the two-system increased.

Comparison between the approximate cost for the Cobiax slab and the post-tension slab with consideration different span length.

Fig. 7 shows the comparison between cost in USD for post-tension system and Cobiax system. As per Fig. 7, it has been found that the post-tension system cost is less than Cobiax.

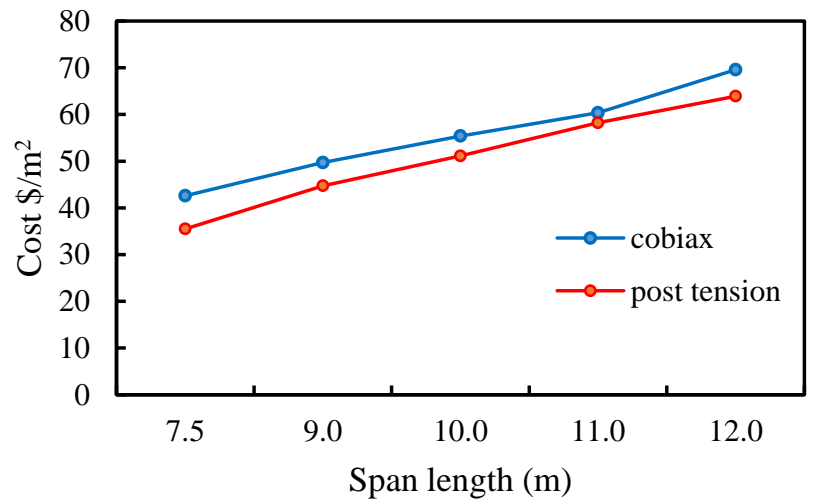

Fig. 7. Comparison based on direct slab cost.

Since the cost of reinforcement bars are more expensive than the concrete, so reducing the reinforcement quantity is more effective to reduce the total cost of the system (Sammut, 2013; Sagadevan \& Roa, 2019).

\section{CONCLUSIONS}

The aim of this study to see the difference between the post-tension slabs and the Cobiax slabs in terms of cost and time required to finish the work.

Based on this study, looking at the project's cost, it was found that the cost of the post-tension slab is more economical than that of the Cobiax, by looking at the savings rate in the amount of reinforcement and concrete, so it has been found that the post-tension provide less reinforcement and considering that the price of reinforcing bars is greater than the price of concrete, therefore, it has been concluded that the cost of post-tension slabs is lower, even in long spans.

On the other hand, looking at the project's milestone, it has been found that the post-tension slabs are faster in terms of removing the shuttering because the established construction system aims to increase the efficiency of the slab, so concrete gets its full strength in a short period of time, unlike the construction system of Cobiax, which is the main goal is to reduce the amount of concrete, which it reduces the weight of the structure, as there is no saving in the time of building construction.

\section{CONFLICT OF INTEREST STATEMENT}

The authors declare that there is no conflict of interest. 


\section{REFERENCES}

[1] Aalami, B. O., \& Kelley, G. S. (2001). Design of concrete floors with particular reference to postTensioning. PTI Technical Notes, (11), 139-145.

[2] Albrecht, C., Albert, A., Pfeffer, K., \& Schnell, J. (2012). Design and construction of two-way spanning reinforced concrete slabs with flattened rotationally symmetrical void formers. Beton- und Stahlbetonbau, 107 (9), 590-600. https://doi.org/10.1002/best.201200027

[3] Brandão, N. (2013). Análise Competitiva de Soluções em Laje Fungiforme e Vigada. [Master Dissertation, Universidade de Lisboa]. Fenix Tecnico Ulisboa. https://fenix.tecnico.ulisboa.pt/downloadFile/3951458 34270/An\%C3\%A1lise\%20Competitiva\%20de\%20So lu\%C3\%A7\%C3\%B5es\%20em\%20Laje\%20Fungifor me\%20e\%20Vigada.pdf

[4] Churakov, A. (2014). Biaxial hollow slab with innovative types of voids. Construction Of Unique Buildinga and Structures, 6(21), 70-88.

[5] CobiaxUSA (2020). Voided Slabs Are A ProblemSolver. voidedconcrete. https://www.voidedconcrete.com/

[6] Eurocode (2004). Design of concrete structures - Part 1-1: General rules and rules for buildings.

[7] Freyermuth, C. L. (1989). Structural Integrity of Buildings Constructed With Unbonded Tendons. Concrete International, 11(3), 56-63.

[8] Hills, F. (2004). Design of Post-Tensioned Slabs Using Unbonded Tendons. Post-Tensioning Institute.

[9] Kang, T. H.-K. (2011). Grout-Bonded versus Unbonded Post-Tensioning Tendon Behavior in Concrete. PTI Convention. Kansas.

[10] Naik, S. R. \& Joshi, D. (2017). A Voided Slab and Conventional Flat Slab; A Comparative Study. International Journal of Science Technology \& Engineering, 4(1), 44-50.

[11] Sagadevan, R., \& Rao, B. N. (2019). Effect of void former shapes on one-way flexural behaviour of biaxial hollow slabs. International Journal of Advanced Structural Engineering, 11(3), 297-307. https://doi:10.1007/s40091-019-0231-7

[12] Sammut, A. (2013). Saving on cost, time, space. Timesofmalta. www.timesofmalta.com/articles/view/20100509/envir onment/saving-on-cost-time-space.306427

[13] Viana, J. C. M. (2017). "COBIAX" Voided Slabs and Post-Tensioned Flat Slabs: Competitive Analyses[Master Dissertation, Instituto Superior Técnico]. Fenix Tecnico Ulisboa. https://fenix.tecnico.ulisboa.pt/downloadFile/5633450 90415648/Extended\%20Abstract\%20\%20Versao\%20final.pdf

[14] Yadav, M. S., Srinath, G., \& Dongre, A. (2018). A comparative analysis of Cobiax-bubble deck system over other. Indian journal of applied research, 17(2), 293-297. 